\title{
Consolidation of Pretrial Proceedings Under Proposed Section 1407 of the Judicial Code: Unanswered Questions of - Transfer and Review
}

\author{
In $1965 \mathrm{Mr}$. Chief Justice Warren submitted to Congress a proposal \\ that would add to Title 28 of the United States Code a new transfer \\ provision drafted by the Judicial Conference of the United States ${ }^{1}$ in \\ response to a recent flood of civil antitrust litigation. Proposed section \\ $1407^{2}$ would create a judicial panel with power to order the temporary
}

1. The Judicial Conference, a permanent organization chartered by Congress, brings together representatives of the federal judiciary from all of the areas of the United States. It carries on a continuous study of the federal courts and recommends rule changes to the Supreme Court and legislation to Congress. See 28 U.S.C. \$ 331 (1964); Maris, Federal Procedural Rule Making: The Program of the Judicial Conference, 47 A.B.A.J. 772 (1961).

2 "Proposed § 1407. Multi-District Litigation

"(a) When civil actions involving one or more common questions of fact are pending in different districts, such actions may be transferred to any district for coordinated or consolidated pretrial proceedings. Such transfers shall be made by the judicial panel on multidistrict litigation authorized by this section upon its determination that transfers for such proceedings will promote the just and efficient conduct of such actions: Provided, however, That no action shall be so transferred without the consent of the district court in which it is pending. Each action so transferred shall be remanded by the panel at or before the conclusion of such pretrial proceedings to the district from which it owas transferred unless it shall have been previously terminated: Provided, however, That the panel may separate any claim, cross-claim, counter-claim, or third party claim and remand any of such claims before the remainder of the action is remanded.

"(b) Such coordinated or consolidated pretrial proceedings shall be conducted by a judge or judges to whom such actions are assigned by the judicial panel on multidistrict litigation. For this purpose, upon request of the panel, a circuit judge or a district judge may be designated and assigned temporarily for service in the transferee district by the Chief Justice of the United States or the chief judge of the circuit, as may be required, in accordance with the provisions of chapter 13 of this title. With the consent of the transferee district court, such actions may be assigned by the panel to a judge or judges of such district. The judge or judges to whom such actions are assigned, the members of the judicial panel on multidistrict litigation, and other circuit and district judges designated when needed by the panel may exercise the powers of a district judge in any district for the purpose of conducting pretrial depositions in such coordinated or consolidated pretrial proceedings.

"(c) Proceedings for the transfer of an action under this section may be initiated by the judicial panel on multidistrict litigation by notice to the parties in all actions in which transfers for coordinated or consolidated pretrial proceedings are contemplated. Such notice shall specify the manner, time, and place of the hearing to determine whether the transfer shall be made. The panel's order of transfer shall be entered in the office of the clerk of the district court of the transferee district and shall be effective when thus entered. With the order so filed there shall be filed the consent of the district courts from 
transfer of civil actions involving common questions of fact to a single district for purposes of coordinated pretrial proceedings, after which the actions would be returned to their original districts for trial. This comment analyzes the powers of the transferee court and judicial panel under the new section. It gives particular attention to the principles which might apply to the difficult problem of appellate review of section 1407 orders, and discusses criteria which the panel might consider in selecting those cases most suited for consolidation.

\section{The History and Mechanics of the Proposal}

Proposed section 1407 resulted from the 1961 conviction of certain electrical equipment manufacturers and executives for conspiracy to violate the antitrust laws. ${ }^{3}$ Soon after the termination of the criminal actions large numbers of civil treble damage actions were filed in the federal courts against the corporate defendants." The possibility that

which the actions are transferred. The clerk of the transferee district court shall forthwith transmit a certified copy of such order to the clerk of the district court of the district from which the action is being transferred.

"(d) The judicial panel on multidistrict litigation shall consist of seven circuit and district judges designated from time to time by the Chief Justice of the United States, no two of whom shall be from the same circuit. The concurrence of four members shall be necessary to any action by the panel.

"(e) When actions are transferred hereunder, no district court refusing to consent to transfer of related litigation may make any order for or permit discovery in conflict with the discovery proceedings in the transferred actions.

"(f) The panel may prescribe rules for the conduct of its business not inconsistent with Acts of Congress and the Federal Rules of Civil Procedure."

3 The criminal indictments charged twenty-nine manufacturing corporations and fortyfour executives with conspiracies in twenty different product lines of heavy electrical equipment with total annual sales in excess of one and a half billion dollars. All the defendants pleaded guilty or nolo contendere. No opinion was published. See references at General Electric Co. v. City of San Antonio, 334 F.2d 480, 482-83 (5th Cir. 1964); Application of California, 195 F. Supp. 37, 39 (E.D. Pa. 1961); Smith, The Incredible Electrical Conspiracy (pt. 1), Fortune, April 1961, pp. 132-33. Seven executives were sent to jail for one month; twenty-three others were given suspended sentences and put on probation for five years. Nearly two million dollars in fines were levied against the twenty-nine corporations, ranging from $\$ 437,500$ to $\$ 7,500$. See Smith, The Incredible Electrical Conspiracy (pts. 1-2), Fortune, April 1961, pp. 132, 133-34, May 1961, pp. 161, 222.

4 Over 1,900 separate treble damage actions were ultimately filed under $\$ 4$ of the Clayton Act, 38 Stat. 731 (1914), 15 U.S.C. $\S 15$ (1964). Most of these were commenced in 1962, increasing fivefold the total number of civil antitrust cases usually filed in the federal district courts during one year. See 1964 DIRECTOR OF THE ADMINISTRATIVE OfFICE OF THE United States Courts ANn. ReP. 151 [hereinafter cited as 1964 Director's ReporT]. “The only other group of private antitrust cases comparable in magnitude to the electrical equipment litigation were the motion picture cases. ... [T] he motion picture cases were fewer, aggregating one-third to one-half the number of electrical equipment suits, and they were filed comparatively evenly over a longer period of time, producing a much smaller load on the courts." Neal \& Goldberg, The Electrical Equipment Antitrust Cases: Novel Judicial Administration, 50 A.B.A.J. 621, 622 (1964). 
this litigation would disrupt entire dockets ${ }^{5}$ prompted the Judicial Conference to create what came to be known as the Co-ordinating Committee for Multiple Litigation ${ }^{6}$ and to confer upon it the unprecedented responsibility of coordinating pretrial proceedings in these cases. ${ }^{7} \mathrm{Al}-$ though handicapped by the lack of a provision in the United States Code or Federal Rules under which a coordinated discovery program could be compelled, ${ }^{8}$ and forced to rely on the voluntary cooperation of often skeptical district judges, ${ }^{9}$ the committee organized a nationally coordinated pretrial program of such success ${ }^{10}$ that the committee was encouraged to concern itself with developing general principles for use in any future similar litigation. ${ }^{11}$ In 1964 the Judicial Conference authorized the committee to explore the possibility of recommending legislation toward this end. ${ }^{12}$

After nearly a year of studying the ad hoc procedures employed in the electrical cases, the committee drafted section $1407^{13}$ on the premise

5 See 1962 Director of the Administrative Office of the United States Courts ANN. REP. 95 [hereinafter cited as 1962 DiREcroR's REPORT]; Neal \& Goldberg, supra note 4, at 622.

61962 Director's Report 95. The Co-ordinating Committee (hereinafter referred to as the committee) was created as a subcommittee of the Judicial Conference's standing Committee on Pretrial Procedure. Ibid.

7 Ibid. Technically the committee was appointed "to consider discovery problems arising in multiple litigation with common witnesses and exhibits." Ibid. " $[\mathrm{I}] \mathrm{n}$ creating the subcommittee the Judicial Conference indicated its belief that the problems of multiple related cases might extend beyond the immediate pressures of the electrical equipment cases and that the general problem merited sustained attention from the conference." Neal \&. Goldberg, supra note 4, at 623.

$8 I d$. at 623.

9 See ibid.; 1963 Director of the AdMinistrative Office of the United States Courts ANN. ReP. 49, 102; 1962 Director's Report 95.

10 National hearings were held by the committee to permit counsel in the cases to express their views before any procedures were recommended for coordinating pretrial proceedings. Appropriate local proceedings were then held by individual judges to hear each party's objections to the recommendations and to implement those recommendations the judge deemed proper. Neal \& Goldberg, supra note 4, at 623-24.

Over thirty-five national pretrial orders were recommended by the committee, providing for uniform interrogatories and document requests, establishing two centralized document depositories containing over one million documents, and governing the scheduling of depositions which were made applicable to all cases. The early determination of common questions of law was expedited by setting up schedules for hearing objections to the complaints. Id. at 624-28. For a comprehensive analysis of the committee and the electrical cases, see Neal \& Goldberg, supra note 4.

11 See 1962 Director's REPORT 78-79.

121964 DiRECTOR's REPORT 42, 43.

13 Co-ordinating Committe for Multiple Litigation of the United States District Courts, Comment on Proposed \& 1407, at 1 (1965) [hereinafter referred to as Committee CommenT]. On the recommendation of its standing Committee on Revision of the Laws, the Judicial Conference approved the draft. 1965 REPORT OF THE JUDICIAL CONFERENCE OF THE United States 12, 13. 
that enforced centralization of pretrial proceedings in related multidistrict cases would minimize the costs and burdens engendered by overlapping and conflicting discovery while preserving the benefits of local trials in the appropriate districts. ${ }^{14}$ Because the committee realized, however, that even a pretrial court must be able to dispose of motions efficiently, section 1407 grants the transferee courts "the usual powers provided by the Federal Rules of Civil Procedure, including authority to render summary judgment, to control and limit pre-trial proceedings, and to impose sanctions for failure to make discovery or comply with pre-trial orders." 15

Under this proposal the transferee court will thus have the traditional pretrial role of all federal district courts, with perhaps one exception. Seemingly implicit in section 1407's requirement that "each action . . . be remanded ... to the district from which it was transferred"16 is the denial to the transferee court of the power to affect the place of trial of any action. The section thus appears to prevent a transfer by this court under other federal transfer provisions. ${ }^{17}$ At first glance this restriction seems insignificant, for there should be no need to enter a permanent transfer order until the end of pretrial proceedings, when the trial court

14 In the committee's words, $\$ 1407$ is designed to "maximize the litigant's traditional privileges of selecting where, when and how to enforce his substantive rights or assert his defenses while minimizing possible undue complexity from multi-party jury trials." CosiMitTeE Conment at 5 .

The transfer of only pretrial proceedings distinguishes $\S 1407$ from the other federal transfer provisions, all of which provide for transfer of actions in their entirety. These are: 66 Stat. 424 (1952), 8 U.S.C. $\S 1105$ (1964) (transfer of proceedings to review deportation orders); 30 Stat. 554 (1938), 11 U.S.C. $\$ 55$ (1964) (transfer and consolidation of proceedings in bankruptcy); 28 U.S.C. $\S 1404$ (a) (1964) (transfer for the "convenience of parties and witnesses" and "in the interest of justice"); 28 U.S.C. $\$ 1406$ (a) (1964) (transfer when an action has been brought in a district of improper venue); 28 U.S.C. $\S 1406$ (c) (1964) (transfer to the Court of Claims when an action has been improperly filed in a district court); 28 U.S.C. \& 1506(b) (1964) (transfer to a district court when an action has been improperly filed in the Court of Claims); 28 U.S.C. $\$ 2241$ (1964) (transfer of habeas corpus proceedings); FED. AdM. R. 54 (transfer of limitation of liability proceedings); Fed. R. CRIM. P. 21(b) (transfer "if in the interest of justice").

While these provisions, with the exception of FED. ADM. R. 54, limit the districts to which the actions may be transferred, $\S 1407$ provides for transfer to any district. Since it is thus possible for a case to be transferred to a district where venue would not have existed had the case been brought there originally, $\S 1407$ is in part a venue statute. Congress may permit venue to lie wherever it chooses. See Neirbo Co. v. Bethlehem Corp., 308 U.S. 165 (1939); Rutland Ry. v. Bhd. of Locomotive Eng'rs, 307 F.2d 21 (2d Cir. 1962).

15 Committee Comment 5.

16 Section 1407 , note 2 supra.

17 E.g., 28 U.S.C. \$ 1404(a) (1964): "For the convenience of parties and witnesses, in the interest of justice, a district court may transfer any civil action to any other district or division where it might have been brought." For other federal transfer provisions, see note 14 supra. 
will be able to do so. But at the end of pretrial the transferee court will be better acquainted than the trial court with any given case and with cases from other districts with which that case might usefully be consolidated for trial. Thus, to the extent that consolidation to avoid multiple trials might be desirable, ${ }^{18}$ the transferee court would seem the logical instrument of implementation. The only reason for the restriction would seem to be that a transferor court, which must agree to any section 1407 transfer, ${ }^{19}$ might be more likely to permit that transfer if it knows that the transferee court cannot undercut its trial jurisdiction. However, this rationale rests on the rather unlikely premise that district courts compete for trials. Even to the extent that this is true, it seems unnecessary so to limit the powers of the transferee court, provided appellate review of a district court's refusal to permit transfer is available. ${ }^{20}$

Interestingly, the committee comments that section 1407 "would not ... exclude transfer under other statutes ... prior to or at the conclusion of pre-trial proceedings." 21 It is unclear whether the limiting phrase should be read as "prior to the conclusion of or at the conclusion of pretrial proceedings," making transfer obtainable at any time during pretrial, or whether it should be read as "prior to pretrial proceedings or at the conclusion of pretrial proceedings," denying transfers while the transferee court has jurisdiction. If the former interpretation is correct, section 1407's apparent limitation on transfer during pretrial must be unintentional. But clearly the committee's language is too ambiguous to provide any substantial justification for a court's reading section 1407 in a way opposed to its literal prohibition of transfers. Hence, unless Congress rewords the provision, the general pretrial powers of the transferee court will probably be limited by the absence of ability to transfer.

The traditional pretrial powers proposed for the transferee court contrast sharply with the unprecedented powers to be given the seven man judicial panel created by the statute. Most important, the panel is given the authority to decide whether transfer will be beneficial in

18 Although the Commitre Comment extols the virtues of separate trials and remarks on the "possible undue complexity from multi-party jury trials," CoMmIrTeE CoMment 6, the committee and the courts are currently engaged in consolidating many of the electrical cases for trial. For the purpose of consolidation to avoid multiple trials there have been more than twenty $\S 1404$ (a) transfers to the Northern District of Illinois of cases involving two specific electrical product lines. See, e.g., I-T-E Circuit Breaker Co. v. Regan, 348 F.2d 403 (8th Cir. 1965); I-T-E Circuit Breaker Co. v. Becker, 343 F.2d 361 (8th Cir. 1965).

19 "[N]o action shall be so transferred without the consent of the district court in which it is pending." Section 1407, note 2 supra.

20 See pp. 572-73 infra.

21 Commitree Comment 3. 
the circumstances and to enter a transfer order ${ }^{22}$ - powers which are confined to district courts under all other federal transfer provisions. ${ }^{23}$ Although the committee analogizes this part of the panel's function to the division of the judicial business of some single districts by executive committees of the district judges, ${ }^{24}$ this analogy is imperfect because the panel must obtain the consent of the transferor court before transferring a case, ${ }^{25}$ while an executive committee need not. ${ }^{26}$ Presumably consent is required because the transferor court will be well acquainted with the cases before it and may detect factors militating against transfer which the panel fails to notice. But a strong argument can be made that such consent is superfluous and should not be required, since it gives the transferor district judge a veto power over a panel composed of seven circuit and district judges. ${ }^{27}$ There is, perhaps, no great need

22 Section 1407, note 2 supra.

23 See note 14 supra for a list of the other federal transfer provisions.

24 Commitien Comment 7-8.

25 Section 1407, note 2 supra. Thus a need for voluntary cooperation of judges similar to that which was difficult to achieve in the electrical cases is only partially eliminated under section 1407.

26 It would appear that one might more usefully conceive of $\S 1407$ as a combination of $\S$ 1404(a), which provides for transfer "for the convenience of parties and witnesses" and "in the interest of justice," and FED. R. Crv. P. 42(a), which permits a court to consolidate pending cases which involve "common questions of fact." Such a view encompasses the power of transfer which the district court executive committees do not possess, § 1407's nature as a venue statute, see note 14 supra, and the availability of any appellate review, see text accompanying note 34 infra. Seen this way, $\S 1407$ is primarily a consolidation statute with a transfer provision attached only as a procedural necessity, and the judicial panel would be more closely analogous to a district court acting under rule 42 (a).

27 The Department of Justice, in response to a request for its views on the bill, recommended an amendment: " $[W]$ e believe that the provision of the bill which requires the consent of the district court from which an action is transferred should be deleted. To require such consent seems superfluous since seven circuit and district judges must consider the proposed transfer and four members of the panel approve it before it can take place. Requiring the consent of the transferor district judge would give a veto power and in essence require voluntary cooperation of all in order to consolidate discovery proceedings."

The Department also recommended that the Government's civil antitrust suits be exempted under the bill, since the Government's purpose in such a suit normally differs from that of a private litigant: the Government is seeking to protect the public, while private litigants are interested in damages for past injuries. On the other hand, the Department stated that government damage suits should be included, for the Government's purpose in such suits is the same as a private party. Accordingly, the Department recommended adding a new subsection (g):

(g) Nothing in this section shall apply to any action in which the United States is a complainant arising under the antitrust laws. "Antitrust laws" as used herein include those acts referred to in the Act of October 15, 1914, as amended (38 Stat. $730 ;$ I5 U.S.C. 12) and also include the Act of June 19,1936 (49 Stat. 1526; 15 U.S.C. 13, 13a and 13b) and the Act of September 26, 1914, as added March 2, 1938 (52 Stat. 116, 117, 15 U.S.C. 56); but shall not include section $4 \mathrm{~A}$ of the Act of October 15, 1914, as added July 7, 1955 (69 Stat. 282; 15 U.S.C. 15a).

Other than recommending these two amendments, the Department approved the legisla- 
to authorize the panel to override district court opposition, since "no district refusing to consent to transfer . . . may make any order for or permit discovery in conflict with the discovery proceedings in the transferred actions." 28 Also, section 1407 permits the panel to prescribe such rules as it may wish for the conduct of its business, ${ }^{29}$ and the panel may therefore devise procedures for arguing before a recalcitrant court, either in person or through a litigant with an interest in transfer.$^{30}$ This would assure that the court hears full and detailed arguments for, as well as against, transfer. Nonetheless, a district court might still arbitrarily and erroneously refuse consent, and, if consent is to be required, appellate review of such a refusal should be available to prevent unwarranted frustration of section 1407's purpose. ${ }^{31}$

Given the consent of the transferor court and compliance with section 1407's standards, the panel's mandate to "promote just and efficient conduct of . . . actions" dictates that it should be able to transfer a case over the opposition of all parties, for more is at stake than the interests of the litigants in any one case. Parties to other cases and the federal court system itself may benefit from transfer and consolidation, and the preference of the parties in one case for a particular pretrial forum should be insufficient to prevent transfer of that case. While section 1407 does not expressly give the panel power to transfer over the opposition of the parties, analogies to the powers of district courts under

tion. Letter From Ramsey Clark, Deputy Attorney General, to Representative Emanuel Celler, Jan. 7, 1966, copy on file in the University of Chicago Law Review office.

28 Section 1407, note 2 supra.

29 Ibid. Among the panel's supplementary powers will be the authority to initiate transfer proceedings on its own motion by giving notice to all affected parties when transfer is contemplated. Ibid. See Swindell-Dressler Corp. v. Dumbauld, 308 F.2d 267 (3d Cir. 1962), indicating due process requires a hearing before a transfer can be lawfully made. But see Kitch, Section 1404(a) of the Judicial Code: In the Interest of Justice or Injustice?, 40 IND. L.J. 99, 123 (1965). The panel will be able to adopt its own procedures for such hearings. Section 1407, note 2 supra. See NLRB v. Mackay Radio \& Tel. Co., 304 U.S. 333 (1938); Louisville Gas \& Elec. Co. v. FPC, 129 F.2d 126 (6th Cir. 1942) (indicating that the Constitution requires no fixed procedures in hearings). After transfer the panel will have. authority to assign judges from the transferee district court, with the consent of that court, to conduct the coordinated pretrial proceedings, and to request interdistrict or intercircuit assignment of judges for this purpose. It will also be able to assign panel members or other judges as deposition judges in any district. These are logical and necessary extensions of the power to provide for coordination; the electrical cases demonstrated that varying numbers of judges may be needed at different times during pretrial. See CommitreE COMMENT 8.

30 It is likely that, as in $\S 1404$ (a) mandamus actions, one of the parties will have an interest in transfer and might represent the panel's position to the court. See Ex parte Fahey, 332 U.S. 258, 260 (1947); Rapp v. Van Dusen, 350 F.2d 806 (3d Cir. 1965); 6 MOore, FEDeral Practice f 54.10(2), at 72.73 (2d ed. 1964).

31 See pp. $572-73$ infra. 
rule $42(a)^{32}$ and section $1404(a)^{33}$ support its existence under section 1407. Congress could, of course, helpfully clarify this issue.

\section{Appellate Review}

Transfer under section 1407 may appeal strongly to a defendant interested in reducing his exposure to repetitive or conflicting discovery, or to a plaintiff interested in benefiting from the expanded scope and possibly reduced expense of joint discovery. Conversely, transfer may be highly distasteful to a litigant interested in depriving his opponent of these benefits, or for whom pretrial in a foreign district will mean inconvenience and expense. These practical effects will make availability of appellate review of section 1407 orders an important issue.

Section 1407 itself fails to mention the availability of any appellate review. The committee merely says that it drafted section 1407 in such a way as to insure that appellate review "when available" would take place in a single circuit court. ${ }^{34}$ The phrase "when available" may indicate that the committee would prefer that review be unavailable altogether. This inference finds support in the committee's statement that the panel's function is to be similar to the allocations made by the executive committees of certain districts, ${ }^{35}$ since appellate review of these allocations is available only on the questions of jurisdiction and venue. $^{36}$ It may be, however, that the committee merely wishes to avoid becoming involved in disputes over the availability of review. ${ }^{37}$ Whatever the reason, section 1407's unfortunate silence on this point seems likely to cause considerable uncertainty in application.

A strong argument can be made that there should be no appellate review of section 1407 transfers. The judicial panel is to consist of seven circuit and district judges designated from time to time by the Chief Justice, ${ }^{38}$ and it would seem that such an august membership should be sufficient to guard against any miscarriage of justice. There is no reason to assume that any court of appeals would be more qualified

32 Miller v. Baird, 239 F. Supp. 754 (E.D. Tenn. 1965); 5 Moore, Federal Practice If 42.02, at 1204 (2d ed. 1964).

33 See I-T-E Circuit Breaker Co. v. Becker, 343 F.2d 361 (8th Cir. 1965); SwindellDressler Corp. v. Dumbauld, 308 F.2d 267 (3d Cir. 1962).

34 Commitre Comment 9-10.

35 See text accompanying note 24 supra.

36 See Levine v. United States, 182 F.2d 556 (8th Cir. 1950), cert. denied, 340 U.S. 921 (1951); Burall v. Johnston, 62 F. Supp. 825 (N.D. Cal. 1945); Burall v. Johnston, 53 F. Supp. 126 (N.D. Cal. 1943), aff'd, 146 F.2d 230 (9th Cir. 1944), cert. denied, 325 U.S. 887 (1945).

37 "The proposed section does not attempt to alter or clarify present doctrines as to the availability or scope of review of transfer orders." Commitree Comment 10.

38 Section 1407, note 2 supra. 
than the panel to judge the issues involved. ${ }^{39}$ But if the panel's decision is to be final and unreviewable, section 1407 should clearly say so. Therefore, while it is suggested that Congress might eliminate all review of panel decisions, it must be assumed that section 1407's present silence will leave to the courts the determination of what review will be available.

The simplest review procedure would be for a court of appeals to review directly the panel's orders, much as district court orders are reviewed. But panel orders do not come within the statutes conferring review jurisdiction on the courts of appeals, ${ }^{40}$ and therefore such direct review of the panel will not be available unless Congress specifically provides for it. The courts of appeals will have to resort to whatever other means of review they might have available, exerting their authority directly over the district courts involved.

Effective appellate review, of course, will have to be interlocutory. Review after final judgment will afford no protection, since the harm of inconvenience and expense will already have been done. Thus, review will have to be by mandamus rather than appeal, since except in certain specific instances not here applicable, ${ }^{41}$ appeals are allowed only from final judgments. ${ }^{42}$ A means of review is suggested, for example, by district court orders under transfer section 1404(a), which are not appealable 43 but are often reviewed in the court of appeals by writ

39 Of course the panel will not be infallible. It is possible that discovery proceedings may unearth facts which were unknown to the panel and which make remand of a given case desirable. But since the panel has the power to remand a case at any time, the possibility of such an error does not compel an alternative judicial remand procedure, as long as it is not impractical or cumbersome to appeal to the panel.

4028 U.S.C. $\$ \$ 1291-94$ (1964) confer jurisdiction on the courts of appeals to review decisions of district and territorial courts, while 28 U.S.C. $\$ 451$ (1964) defines "district court" as a court constituted by chapter 5 of title 28. Nor do panel orders come within the review jurisdiction conferred on the courts of appeals by other statutes. See the reviser's notes at 28 U.S.C. $\S 1291$ for a list of these statutes. Panel orders do not come within the statutes conferring jurisdiction on the Supreme Court, either. See 28 U.S.C. $\$ \S 1251-58$ (1964).

41 Congress has recognized the need for interlocutory appeals in the following instances: 66 Stat. 423 (1952), 11 U.S.C. $§ 47$ (1964) (bankruptcy proceedings); 28 U.S.C. $\S 1252$ (1964) (orders invalidating federal statutes); 28 U.S.C. $\S 1253$ (1964) (injunctions issued or refused by statutory three judge courts); 28 U.S.C. $\$ 1292$ (1964) (certain cases involving injunctions, receivers, admiralty, or patents, or when a district judge certifies that an immediate appeal may materially advance the ultimate termination of the litigation); 28 U.S.C. $\S 1447$ (d) (1964) (civil rights removal petitions).

42 Long v. Union Pac. R.R., 206 F.2d 829 (10th Gir. 1953); Breeding Motor Freight Lines, Inc. v. Reconstruction Fin. Corp., 172 F.2d 416, 425 (10th Cir.), cert. denied, 338 U.S. 814 (1949). See also DiBella v. United States, 369 U.S. 121 (1962); Sears, Roebuck \& Co. v. Mackey, 351 U.S. 427 (1956).

43 E.g., Grossman v. Pearlman, 353 F.2d 284 (2d Cir. 1965); Littman v. Bache \& Co., 246 F.2d 490 (2d Gir. 1957). In some cases appeal has been allowed from $\$ 1404$ (a) orders, 
of mandamus ${ }^{44}$ under the general authority of the All Writs Act.45

Since the two situations in which a party might wish to seek mandamus in connection with a section 1407 order-when he opposes a granted or proposed transfer, and when he desires but is refused transfer - differ significantly, each must be analyzed separately to determine whether and to what extent appellate review might be available under section 1407.

\section{Review of Transfer Orders}

First, consider the party opposed to transfer. After his case has been transferred, he might petition the transferee court for remand. ${ }^{46}$ If this is denied, ${ }^{47}$ he could then petition the transferee circuit court for a writ of mandamus ordering the district judge to remand the case. ${ }^{48}$ The

but in those cases the orders effectively terminated the litigation. E.g., United States v. Berkowitz, 328 F.2d 358 (3d Cir.), cert. denied, 379 U.S. 821 (1964); Hohensee v. News Syndicate, Inc., 286 F.2d 527 (3d Cir.), rev'd on other grounds, 369 U.S. 659 (1961).

A strong argument has been made that transfer orders ought to be final and appealable under the doctrine of Cohen v. Beneficial Industrial Loan Corp., 337 U.S. 541 (1948). See Note, Appealability of 1404(a) Orders: Mandamus Misapplied, 67 YAlE L.J. 122 (1957). In Cohen the Court interpreted 28 U.S.C. $\$ \S 1291$ and 1292 as indicating "the purpose to allow appeals from orders other than final judgments when they have a final and irreparable effect on the rights of the parties." 337 U.S. at 545. The Court held an otherwise interlocutory order appealable because it was a "final disposition of a claimed right which is not an ingredient of the cause of action and does not require consideration with it." 337 U.S. at 546-47. Although transfer orders have these characteristics, the courts have explicitly held the Cohen doctrine inapplicable. E.g., Shapiro v. Bonanza Hotel Co., 185 F.2d 777 (9th Cir. 1950); Ford Motor Co. v. Ryan, 182 F.2d 329 (2d Cir.), cert. denied, 340 U.S. 851 (1950).

44 E.g., Van Dusen v. Barrack, 376 U.S. 612 (1964), reversing 309 F.2d 953 (3d Cir. 1962); Swindell-Dressler Corp. v. Dumbauld, 308 F.2d 267 (3d Cir. 1962).

45 "The Supreme Court and all courts established by Act of Congress may issue all writs necessary or appropriate in aid of their respective jurisdictions and agreeable to the usages and principles of law." 28 U.S.C. § 1651(a) (1964).

46 The request would assert that the panel erred in making the transfer and perhaps even that the transferee court consequently lacks jurisdiction. A party might also request retransfer under \& I404(a) on the basis of the "convenience of parties and witnesses" and the "interest of justice," since no doctrine of the law of the case has developed under present transfer provisions. See, e.g., United States Lines Co. v. MacMahon, 285 F.2d 212 (2d Cir. 1960); Sypert v. Miner, 266 F.2d 196 (7th Cir.) cert. denied, 361 U.S. 832 (1959); Kitch, supra note 29, at 129-30. But see Atlantic Coast Line R.R. v. Davis, 185 F.2d 766 (5th Cir. 1950); I MOORE, FedERAL Practice I 0.145, at 1769 (2d ed. 1964). This might, of course, put a case in orbit. See Kitch, supra note 29, at 129-30.

47 It may be assumed that the transferee district judge would almost always deny remand, at least when no more facts are available to him than were available to the judicial panel which transferred the case. The propriety of the transfer would then be litigated in the court of appeals. Such a possibility presents the interesting anomaly of a district or circuit court contradicting a panel of seven district and circuit judges, which is an important factor arguing against review of a $\$ 1407$ order. See text accompanying notes 38-39 supra.

48 One might argue that if the transfer order is faulty and the lower court consequently 
availability of review depends upon whether the circuit court has power to issue mandamus in such circumstances. At one time many circuits might have denied that they had such power, ${ }^{49}$ but in La Buy v. Howes Leather Co. ${ }^{50}$ the Supreme Court stated, with regard to the circuit courts' general "power" to issue the writ:

The question of naked power to issue mandamus has long been settled by this Court. . . . Since the Court of Appeals could at some stage of the antitrust proceedings entertain appeals in these cases, it has power in proper circumstances, as here, to issue writs of mandamus reaching them. ${ }^{51}$

We believe that supervisory control of the District Courts by the Courts of Appeals is necessary to proper judicial administration in the federal system..$^{52}$

The courts of appeals have altered their treatment of transfers in the aftermath of $L a B u y^{53}$ and it appears that the transferee circuit will be

lacks jurisdiction, the circuit court would have no jurisdiction or need to order a retransfer. See Kitch, supra note 29, at 111 n.46, 118 \& n.84, 120 n.92. But in Magnetic Engineering \& Manufacturing Co. v. Dings Manufacturing Co., 178 F.2d 866, 870 (2d Cir. 1950), the Second Gircuit said that even an erroneous $\$ 1404$ (a) transfer vested jurisdiction in the transferee courts, and that the transferee appeals court would have authority to direct the transferee district court to remand the case. The Supreme Court, in Hoffman v. Blaski, 363 U.S. 335, 343 (1960), while holding that "the transferee courts could have acquired jurisdiction over these actions only if . . . validly transferred thereto . . ." and that the actions had been improperly transferred under $\S 1404(a)$, affirmed the order of the transferee appeals court granting mandamus and directing remand. The court did not explain how, if the district court lacked jurisdiction, the circuit court, or indeed the Supreme Court, acquired jurisdiction, nor why it was necessary to remand if the case was never really transferred. The federal courts generally ignore this issue, tacitly assuming the position of the Second Circuit. See Bankers Life \& Cas. Co. v. Holland, 346 U.S. 379, 382 (1953); GuIf Research \& Dev. Co. v. Leahy, 193 F.2d 302, 304 (3d Cir. 1951), aff'd, 344 U.S. 861 (1952).

49 At one time, for example, the First Circuit denied the existence of power to review any transfer order except one transferring a case out of the circuit, on the rationale that only then was its appellate jurisdiction endangered. In re Josephson, 218 F.2d 174 (1st Cir. 1954). The Eighth Circuit followed a narrow approach similar to that of the First Circuit. Great No. R.R. v. Hyde, 238 F.2d 852 (8th Cir. 1956), aff'd on rehearing, 245 F.2d 537 (8th Cir.), cert. denied, 355 U.S. 872 (1957); Carr v. Donohue, 201 F.2d 426 (8th Cir. 1953).

50 352 U.S. 249 (1957), affirming, 226 F.2d 703 (7th Cir. 1955).

51352 U.S. at 255.

52 Id. at 258.

53 Subsequent to $L a B u y$, in a mandamus case not involving transfer orders, the First Gircuit cited that case as requiring a more liberal view of the mandamus power and referred to its changed attitude, citing In re Josephson, supra note 49 , to indicate its old position. In re Union Leader Corp., 292 F.2d 381, 383 (1st Cir.), cert. denied, 368 U.S. 927 (1961) (petition for mandamus to disqualify a district judge). Similarly, the 
empowered to issue mandamus ordering remand of a section 1407 transfer.

Granting that the power exists, the effectiveness of review of transfers into a circuit will depend upon the circumstances in which the courts will issue the writ. La Buy leaves this to the discretion of the circuit courts, which usually decide in terms of the district courts" "abuse of discretion" or "manifest judicial arbitrariness," or the existence of "exceptional circumstances." 54 The practical significance of these phrases is that mere error in the exercise of discretion by a district judge is insufficient to justify issuing the writ..$^{55}$ Generally, sufficient cause is found only in instances where a trial court's action has been in excess of its "jurisdiction," 56 such as transferring to a district where

Eighth Circuit has changed its position and now considers itself to have "power" to review transfer orders generally. McGraw-Edison Co. v. Van Pelt, 350 F.2d 361, 363 (8th Cir. 1965). This case also overrules the decision on rehearing in Great No. R.R. v. Hyde, 245 F.2d 537 (8th Cir.), cert. denied, 355 U.S. 872 (1957), which, interestingly enough, came after La Buy. See note 49 supra.

Of course, since actions under $\S 1407$ are to be remanded to the original districts for trial, it can be argued that the transferee circuit court will be unable to entertain appeals from final judgment, and will thus be unable to issue mandamus even according to the standard in $\mathrm{La} \mathrm{Buy.} \mathrm{But} \mathrm{the} \mathrm{transferee} \mathrm{circuit} \mathrm{court} \mathrm{might} \mathrm{have} \mathrm{to} \mathrm{assert} \mathrm{its} \mathrm{appellate}$ jurisdiction should the district court exercise its power of summary judgment. Also, La $B u y$ was based not only on the potential ability to entertain appeals but also on the responsibility of the courts of appeals to exercise supervisory control over the district courts, and if the transferee circuit court does not have supervisory control of $\S 1407$ pretrial proceedings no circuit does. Thus, it appears that the transferee circuit will be empowered to issue mandamus.

54 The First, Second, Sixth, and Ninth Circuits indicate that issuance of the writ is reserved for extraordinary circumstances, although they have difficulty defining what is extraordinary. See Grossman v. Pearlman, 353 F.2d 284 (2d Cir. 1965); Pennsylvania R.R. v. Connell, 295 F.2d 32 (6th Cir. 1961); In re Union Leader Corp., supra note 53; Lykes Bros. S.S. Co. v. Sugarman, 272 F.2d 679 (2d Cir. 1959); Lemon v. Druffel, 253 F.2d 680 (6th Cir.), cert. denied, 358 U.S. 821 (1958); Gulf Research \& Dev. Co. v. Harrison, 185 F.2d 457 (9th Cir. 1950).

By comparison, the Third Circuit will not grant mandamus when a trial judge has considered and passed upon the interests stipulated in the transfer statute. All States Freight, Inc. v. Modarelli, 196 F.2d 1010 (3d Cir. 1952). But see Swindell-Dressler Corp. v. Dumbauld, 308 F.2d 267, 272 (3d Cir. 1962). The Eighth Circuit speaks of manifest judicial arbitrariness. McGraw-Edison Co. v. Van Pelt, 350 F.2d 361 (8th Cir. 1965). The Seventh and Tenth speak of abuse of discretion. Houston Fearless Corp. v. Teter, 318 F.2d 822 (10th Cir. 1963); Butterick Co. v. Will, 316 F.2d 111 (7th Cir. 1963).

55 E.g., Butterick Co. v. Will, supra note 54; Chemical \& Indus. Corp. v. Druffel, 301 F.2d 126 (6th Cir. 1962); Sypert v. Miner, 266 F.2d 196 (7th Cir.), cert. denied, 361 U.S. 832 (1959).

56 See Comment, Mandamus Proceedings in the Federal Courts of Appeals: A Compronise with Finality, 52 CALIF. L. REv. 1036, 1045-47 (1964).

This reluctance to issue the writ is apparently due to fear of the impact of mandamus on the calendars of appellate courts and the progress of proceedings below. See La Buy v. Howes Leather Co., 352 U.S. 249, 268 (1957) (Brennan, J., dissenting); Crick, The Final Judgment Rule as a Basis for Appeal, 41 YALE L.J. 539, 551 (1932); Kitch, supra note 29, 
the action could not have been brought; ${ }^{57}$ transferring without a hearing, in denial of due process; ${ }^{58}$ or transferring in contravention of a constitutional policy. ${ }^{59}$

Practice under the present case law thus indicates that the circuit courts will most probably hold that they have power to review transfer of actions into their circuits under section 1407, but in practice they will rarely issue the writ. They will probably be quick to mandamus the district court if they find a transferred action does not have a "common question of fact" with other actions, since this will go to the panel's power to transfer. But parties desiring reversal of a section 1407 transfer will most often have to ground their attack on the substantive requirement that transfers must promote the "just and efficient" conduct of the actions, for in all but the most exceptional cases which the panel might conceivably wish to transfer, common questions of fact will clearly exist. Because the panel's "abuse of discretion" must be asserted, the courts' reluctance to issue the writ under section 1404(a) to overturn a discretionary finding of convenience and justice indicates that reversal on this ground will probably be rare in section 1407 cases. Since the place of pretrial proceedings is generally of less importance than the place of trial, the courts of appeals will almost certainly defer to the expertise of the specially appointed and knowledgeable panel of their peers even more often than they do in reviewing district court transfer orders under section 1404(a).

Some parties, of course, will desire to have review of a transfer order in the transferor circuit, but the transferor circuit court does not have power to order the transferee district court to remand an action unless the transferor and transferee districts are in the same circuit. Since the transfer will be effective once the panel enters the order, ${ }^{60}$ if the trans-

at 117 \& $n .79$. This reluctance seems to be borne out by the experience of the Seventh Circuit. After a period of liberally granting mandamus in \& 1404(a) cases, the Seventh Circuit received an increased number of petitions for mandamus and consequently cautioned attorneys that they should not file such petitions unless they could make out a strong case of abuse of discretion. Sypert v. Miner, supra note 55. Since then, the court has issued the writ only once, in a criminal case where it found a refusal to transfer was in violation of a constitutional policy. Minnesota Mining \& Mfg. Co. v. Platt, 314 F.2d 369 (7th Cir. 1963), rev'd, 376 U.S. 240 (1964). See Kitch, supra note 29, at 124-25.

57 Barrack v. Van Dusen, 309 F.2d 953 (3d Cir. 1962), rev̛d, 376 U.S. 612 (1964); Behimer v. Sullivan, 261 F.2d 467 (7th Cir. 1958), aff'd sub nom. Blaski v. Hoffman, 363 U.S. 335 (1960); Blaski v. Hoffman, 260 F.2d 317 (7th Cir. 1958), aff'd, 363 U.S. 335 (1960).

58 Swindell-Dressler Corp. v. Dumbauld, 308 F.2d 267 (3d Cir. 1962).

59 Minnesota Mining \& Mfg. Co. v. Platt, 314 F.2d 369 (7th Cir. 1963), rev'd, 376 U.S. 240 (1964).

60 "The panel's order of transfer shall be ... effective when . . . entered." Section 1407, note 2 supra. Filing of the papers in the transferee court effects the transfer at present, removing the case from the jurisdiction of the transferor district and its circuit court. 
feror circuit is to intervene it must be able to do so before the panel transfers the case or else be able to speak with authority directly to the judicial panel. The only pretransfer review available would be review of the district judge's consent to transfer, and the time interval during. which a party would be able to petition for such review is likely to be too short to make such review effective, for the panel will probably not request the district court to consent, nor will the district court be likely to consent, until after the panel has decided to transfer. Nor do the courts of appeals have power to give direct review of the panel. ${ }^{61}$

Even if a transferor circuit should determine that it has a general mandamus power over the panel, it will probably not exercise it. Any court construing section 1407 will have to give great weight to the committee's statement that the section was purposefully drafted in such a way as to insure that appellate review of transfers would take place in one court of appeals. ${ }^{62}$ The only need for review in the transferor circuit would be to save a party from whatever additional expense is involved in appealing a possibly faulty order in a foreign circuit, or to protect the transferor circuit's appellate jurisdiction. It is to be expected that relatively few section 1407 transfer orders will be reversed, so that few litigants will have to travel unnecessarily; and the transferor circuit's potential appellate jurisdiction will be protected by section 1407's requirement that actions must be remanded to their original districts for trial. ${ }^{63}$ The loss of jurisdiction to review discovery is not sufficiently important to require review of the transfer order; one circuit's review of discovery is enough. Moreover, whatever considerations may favor review in the transferor circuit would seem to be entirely overborne by the benefits to be gained from restricting review to the transferee circuit, for a court with all of the cases before it will be able to see more clearly the relationships between the cases, to judge more easily whether common questions of fact exist, and to decide more accurately whether the just and efficient conduct of the litigation will be

Brabik v. Murphy, 246 F.2d 408 (2d Cir. 1957); Magnetic Eng'r \& Mfg. Co. v. Dings Mfg. Co., 178 F.2d 866 (2d Cir. 1950); Fisher v. United Air Lines, Inc., 218 F. Supp. 223 (S.D. N.Y. 1963).

61 See text accompanying note 40 supra.

62 Commites CoMment 9-10.

63 The transferee court's power to render summary judgment (see text accompanying note 15 supra) presumably would not be sufficient in itself to operate as a threat to the transferor circuit's potential appellate jurisdiction. If $\S 1407$ should be amended to permit the transferee court itself to transfer the actions under other federal transfer provisions, however, protection of appellate jurisdiction will be considerably lessened. See text accompanying note 20 supra. But to use this as a justification for review in the transferor circuit is to approve of competition for cases, which should be discouraged since it serves no useful function and can only operate to the detriment of judicial efficiency. 
promoted by transfer. Exclusive appeal in the transferee circuit might possibly result in a temporarily heavy appellate load in that circuit, but this could easily be alleviated by transfer of judges under 28 U.S.C. $\$ 291 .^{64}$ Indeed, in many instances it will be more efficient to deal with this temporary overload in one circuit than to deal with one-tenth the overload in ten circuits.

\section{Review of Refusals to Transfer}

While the preceding analysis dealt only with the availability of review to rescind or prevent transfer, cases are certain to arise in which the panel will refuse transfer or a district court will refuse to consent. The availability of appellate review of such refusals will also be an important issue.

If any court is to give relief when the panel refuses to transfer a case, it must have authority over the panel, because only the panel has the power of transfer under section $1407 . .^{65}$ It is not clear that any court will have this authority, but even positing such authority, a party should probably be denied relief because he has no "right" to consolidation, which is the sole objective of transfer. While consolidated pretrial may be less expensive to a party and may result in a broader and more thorough discovery, these interests alone appear to be insufficient to overcome the policy against piecemeal appeal. This rationale is reflected in the present trial consolidation rule, Federal Rule 42(a), which grants litigants no right to consolidation even if the requirements of the rule are met. ${ }^{66}$ In only one case does it appear that the appellate courts have granted so much as a hearing on an interlocutory petition requesting review of a refusal to consolidate, and in that case the court declined on the merits to issue the writ. ${ }^{67}$ The only other reason for permitting review would be to provide additional assurance that the vital interest of efficiency in the federal court system, for the furtherance of which section 1407 is primarily designed, will be served. But it would appear that the panel alone will be sufficient to accomplish this purpose, which indeed might be defeated by unnecessary appeals from panel refusals to transfer.

When, however, a district judge refuses to consent after the panel

64 This section provides for intercircuit assignment of judges by the Chief Justice.

65 "Such transfers shall be made by the judicial panel ...." Section 1407, note 2 supra.

66 Sce Blume, Free Joinder of Parties, Claims, and Counterclaims, 2 F.R.D. 250, 259 (1941); Comment, Consolidation in Mass Tort Litigation, 30 U. CHI. L. REv. 373, 375 (1963).

67 MacAlister v. Guterma, 263 F.2d 65 (2d Cir. 1958) (allowing interlocutory appeal under the doctrine of Cohen v. Beneficial Indus. Loan Corp., 337 U.S. 541 (1948). See note 43 supra). 
has decided that coordinated pretrial would promote the just and efficient conduct of the actions, the need for additional assurance that the interests of the federal court system are being properly served would seem to justify granting an interlocutory appeal. The best solution might be to deny the district judge veto power over the panel. ${ }^{68} \mathrm{But}$ if Congress does not delete this veto power, the traditional mandamus power of the circuit courts over the district courts should ensure review of the refusal to transfer. The only question would seem to be whether section 1407 is intended to confer an absolute right on the district judge to refuse his consent. The sole justification for such unlimited discretion would be the prevention of excessive interlocutory appeals; but the appellate courts can sharply curtail the danger of frivolous interlocutory appeals by entertaining only those petitions which show a strong likelihood that claims are presented which, if borne out on argument, will result in issuance of the writ. In this way the courts could prevent the delay and expense of unnecessary interlocutory appeal while assuring that the interests of the federal judicial system in avoiding duplication of effort in pretrial proceedings are protected against district court abuse of discretion. It should be relatively simple to determine whether there has been an abuse of discretion; that is, whether the district judge has a reasonable basis for holding that transfer of the particular case would not promote the just and efficient conduct of the actions in light of the general interest in consolidation and the parties' interests in the particular circumstances.

\section{Griteria of Transferability}

Deservedly, section 1407 is certain to be praised in light of its objective of economy for the litigants and the courts. The panel, however, will have to decide what precise limitations should operate on its. discretion to transfer.

The first factor the panel might consider in deciding whether to transfer is suggested by the circumstances which generated the proposal: the number of cases to be consolidated. Typically, cases transferred under section 1407 will involve numerous plaintiffs and relatively few defendants, with the result that the expense and inconvenience caused a given plaintiff by pretrial in a foreign district will be fairly independent of the number of cases involved, while the benefit to defendants in terms of relief from overlapping discovery and the benefit to the federal judiciary in terms of decreased work and relief of over-

68 See text accompanying note 27 supra. 
crowded dockets will increase rapidly as the number of cases increases. ${ }^{69}$ Hence the smaller the number of cases involved, the less likely that the gain in efficiency will exceed the cost and inconvenience of transfer.

The second factor the panel might consider is the number and complexity of the factual issues unique to each case, as compared with the issues common to all. If the cases contain a number of complex, individualized issues, the gain in efficiency through coordinated pretrial on the common issues may be offset by the cost to parties of inconvenient pretrial on the non-common issues. A solution to this problem, of course, would be coordinating discovery on the common issues while staying discovery on the dissimilar issues until remand. This would be similar to the practice of holding separate trials on the issues of liability and damages in tort cases ${ }^{70}$ and the practice under rule 42(a) of consolidating only on selected issues. ${ }^{71}$ The effectiveness of such a procedure would depend on the ability of the panel to segregate the issues to be investigated at pretrial. Section 1407 does not provide for the transfer of actions in part, ${ }^{72}$ nor does it give the panel authority to limit the transferee court's scope of inquiry. However, the panel does have authority to remand cases before the conclusion of pretrial, and this authority, coupled with the transferee district's desire to cooperate in achieving section 1407's objectives and to avoid taking on time-consuming jobs, may be sufficient to give the panel effective control. Ideally, Congress could give the panel clear-cut authority to segregate issues.

A third factor which the panel might consider is the pattern of settlement in many types of cases. Mass tort cases, such as air crashes, for example, in which liability is either clear or limited because of 'damage

69 Consolidation under $\S 1407$ will seldom be without its price. Many parties may find it inconvenient and expensive to conduct pretrial in a foreign district. Also, when actions are coordinated for pretrial, more intensive discovery can be conducted than otherwise. In particular, parties can obtain relatively inexpensively the depositions of witnesses they would not otherwise interrogate, and the incentive to determine what discovery might be unnecessary is lost. Further, a successful coordinated pretrial depends heavily on the ability of counsel to organize for effective cooperation; otherwise, the court is forced to organize the proceedings in detail. See Neal \& Goldberg, The Electrical Equipment Antitrust Cases: Novel Judicial Administration, 50 A.B.A.J. 621, 625 (1964). This involves time and effort. However, these effects may also decrease with a smaller number of cases.

70 See Hosie v. Chicago \& N.W. Ry., 282 F.2d 639 (7th Cir. 1960), cert. denied, 365 U.S. 814 (1961), 74 HaRv. L. Rev. 781 (1961).

71 See United States v. Holtz, 54 F. Supp. 63 (N.D. Cal. 1944), aff'd sub nom. Kuehn v. United States, 162 F.2d 716 (9th Cir.), cert. denied, 332 U.S. 837 (1947); Hotel George V v. McLean, I F.R.D. 241 (D.D.C. 1940); Comment, supra note 66, 30 U. CHr. L. REv. at 377.

72 Section 1407 does give the panel authority to separate any claim, cross-claim, counterclaim or third-party claim and remand it before the remainder of the action is remanded, see note 2 supra, but this does not give the panel authority to separate any issue. 
ceilings, will seldom reach the courts, for the defendant will settle without permitting the case to be litigated. Even if the trial stage is reached, one or two trials usually establish a pattern for settlement. ${ }^{73}$ It will nearly always be less costly in terms of time and money, both for the courts and the parties, to conduct pretrial of a single action and to try it individually than to conduct coordinated pretrial proceedings for fifty different cases when only one is likely to come to trial. ${ }^{74}$ Such established settlement patterns may in many instances indicate to the panel that transfer will be unnecessary.

\section{CONGLUSION}

By allowing discovery on common questions of fact to be conducted simultaneously for related cases, section 1407 should eliminate duplication of effort and attendant cost and congestion. In order to facilitate achievement of this goal, however, it would seem that in several areas the operation of the statute should be clarified and perhaps extended. For instance, Congress could easily clarify the power of the transferee court to order a further transfer of cases to the most convenient forum for trial and also the power of the panel to transfer over the opposition of parties. This might avoid needless litigation and possibly a deleterious decision. Congress should also take a clear stand on the problem of interlocutory review. It is suggested that Congress should seriously consider eliminating any appellate review of section 1407 orders in light of the safeguard of the large and august panel membership. Even if Congress is unwilling to eliminate review entirely, it should indicate what review is to be available, and should at least indicate that the transferor district judge does not have unlimited discretion to refuse his consent to transfer. Also, in order to facilitate the efficient operation of the section in cases where many non-common issues exist, Congress should give the panel clear authority to limit the issues for which coordinated discovery may be held. These measures would prevent much needless expense and greatly enhance the value of the proposal.

73 See Galiher, The Defendant's Lawyer Looks at Settlement, 31 INs. CounseL J. 65 (1964). Since July 1960 there have been four major air crashes in Illinois. 1962 CAB ANN. REP. 45, 46; 1961 GAB ANN. REP. 39, 40. Only a few scattered cases have come to the attention of the courts and no opinions have been published.

74 In United States v. United Air Lines, Inc., 216 F. Supp. 709 (E.D. Wash. 1962), modified, 335 F.2d 379 (9th Cir.), cert. dismissed, 379 U.S. 951 (1964), a large number of the claims arising from a single air crash were consolidated for pretrial and trial. Discovery was "exceedingly expensive, extensive, and burdensome in time and effort." Id. at 712. AIthough the accident occurred in April 1958 and "in spite of the very great diligence of counsel in their conduct of discovery proceedings," a pretrial order could not even be framed until October 1961. Id. at 712-13. 
The panel and the courts can also facilitate the efficient operation of this section. The transferor appeals court, for example, should decline to review any transfers under section 1407, leaving such review to the transferee circuit, and should also decline to review a refusal of transfer by the panel. This court should, however, review a refusal of consent by the transferor district judge, and should order him to consent if he abuses his discretion. This would help assure proper serving of the interests of the federal court system.

The panel, for its part, might consider three factors in deciding whether to transfer: the number of cases to be consolidated; the number and complexity of issues unique to each case; and the pattern of settlement in the particular cases to be consolidated. If the panel has the ability to segregate the issues to be investigated at pretrial the efficient operation of section 1407 can be extended. 